\title{
8
}

\section{Designed, not copied: the making of public management as a design- oriented professional discipline}

This book, as you know, is about public management. What's public management for? It's for creating public value. What does effectuating public value creation involve? Two lines of theorizing are both pertinent: (a) performing a public organization's enterprise functions, including program-delivery and management, and (b) problem-solving in organizations. The latter is about doing the former better than would otherwise be the case.

What does public management consist in? Two layers of mechanisms, ${ }^{1}$ in particular: design-projects and professional activities, both of which are important to problem-solving and performing a public organization's enterprise functions. Design-projects combine designing new enterprise mechanisms, such as systems and plans, with making organizational decisions. Professional activities are a family of mechanisms of professional practice, in relation to which individual professional practitioners are agents, and they include sense-making, designing, argumentation, and dramatization. How well problem-solving is accomplished and how well enterprise functions are performed affect what public management is for: creating public value. ${ }^{2}$ Thus, public management is a professional practice, for effectuating the intent of public organizations, consisting in design-projects, as well as a family of professional activities.

What's this book for? Broadly, it's to improve public management as a professional practice. What is involved in improving professional practice? It's about fostering a virtuous circle between "doing" and "learning." ${ }^{3}$ What does this book consist in? It consists in two layers of argumentative discussion. One is about a distinctive system of ideas - labeled as design-oriented public management - that is offered as professional knowledge appropriate for the professional practice of public management. Another is a distinctive view - labeled as a design-oriented professional discipline - about how public management should be thought of as an enterprise for improving professional practice.

These two layers of argumentative discussion fit together, to make a consistent whole, in two respects. First, the very idea of public management as a professional 
practice, with a distinct design-oriented profile, will not become part of the professional life of multiple thousands of individuals working in public organizations, unless public management acquires properties of being a professional discipline, patterned on Herbert Simon's vaunted concept of a science of the artificial, but adapted properly to management. ${ }^{4}$ Second, without such a professional discipline, professional practitioners won't benefit from the opportunity to examine and use "professional knowledge" as they engage in the doing and learning functions of their professional practice, whether that knowledge about public management consists in purposive theorizing, or in design-precedents. ${ }^{5}$ Thus, this book is an argument about the enterprise of public management as a design-oriented professional discipline, one that becomes an institution supporting problem-solving and performing a public organization's enterprise functions, irrespective of place and time.

While there are precedents for what has just been said about public management and professional practice, the overall line taken here hasn't been put forward before. In the light of that statement, I'll offer a few remarks about the novelty and positioning of this book.

Let's take the idea that public organizations effectuate public value creation, most directly by delivering public programs (except in cases when public organizations are in a leadership and/or service role within government). This statement derives from Mark Moore's widely cited 1995 book on public management, in particular the intricately formulated and brilliantly argued Chapter 2 of that volume. In this respect, what's novel about the present book is little more than the labeling of such a discussion as a purposive theory of public organizations and the incorporation of the term "effectuation" as a verbal marker of purposive theorizing, as a distinctive form of argumentative discussion.

Let's turn to the idea that a public organization's intent is effectuated by a multitude of mechanisms, any one of which can be theorized, or represented for practical purposes, as a scenario-process. Although this vocabulary is not universal, the idea is so commonplace that it practically operates as a presupposition within the field of program planning/evaluation as well as within the field of management and organizations - if not in public management. Reference to some classics makes the point.

A classic in program planning/evaluation is Pawson and Tilley's Realistic Evaluation. ${ }^{7}$ One of its premises - and take-aways - is that any program can be represented, for either design or evaluation purposes, by the formula, $\mathrm{C}+\mathrm{M}=\mathrm{O}$. Pawson and Tilley's formula appears to symbolize the virtues of understanding how a program works to effectuate program intent by observing and analyzing how a combination of program context and program activity eventuates in program outcomes. (You'll have to overlook their troublesome use of the term "mechanism" to avoid stumbling as you read the previous statement.)

A classic about organizations is Mintzberg's Designing Effective Organizations: Structures in Fives. ${ }^{8}$ Mintzberg posits that no organization can be effective if it is deficient in coordinating its working parts and the tasks they carry out. Among other things, Mintzberg identified distinct forms of scenario-processes 
that are for performing an organization's coordination function, labeling them "coordination mechanisms." These different forms of coordination-performing mechanisms were, characteristically, five-fold: direct supervision, standardization by procedure, standardization by output, standardization by skill, and mutual adjustment. He also discussed how an organization's use of such mechanisms tends to form patterns, shaping and reinforcing power balances within bureaucracies, private or public. Mintzberg's book on organization design clearly illustrates mechanism-intent theorizing about organizations.

Another classic is Michael Porter's Competitive Advantage. ${ }^{9}$ Among other things, Porter identified the configuration of an enterprise's value chain as a mechanism to create value for the purchaser/users of a business' products and services, while neutralizing the ill-effects of competition on a company's profits. Here, a business' value chain configuration is a multitude of mechanisms, which perform each and all of its functions (which Porter termed a business' value activities), so as to effectuate company intent, revolving around profitability. A value-chain's multitude of mechanisms, in turn, consists in scenarioprocesses (as in research and development) and conversion-processes (as in production).

In mentioning these classics, my well sign-posted point is to suggest that this book's style of theorizing public organizations is deeply rooted in precedent. The connection to precedent is, however, not that easy to see, because those who engage in mechanism-intent, purposive theorizing in management tend to be coy about presenting the ideas that "stand above" the ideas that they offer up. This book's novelty lies in part in its retrieval and use of forms of theorizing that have long been prevalent, even if they are not altogether fashionable.

That said, this book goes further than its precedents in theorizing scenarioprocesses along lines known within sociology as "processual sociology". Seeing organizations as consisting in scenario-processes is hardly original: within organization studies, there's more than one intellectual tradition for doing so - for example, one focusing on decision-making in organizations, as well as ones that take cues from structuration theory ${ }^{11}$ or actor-network theory. ${ }^{12}$ However, in my view, works about management that engage fully with purposive theorizing - like the two classics just discussed - tend not to engage fully with processual sociology. Conversely, works that engage fully with processual sociology don't tend to engage fully with purposive theorizing about management. There are plenty of exceptions to this broad pattern; two were presented in Chapter 4, Bryson's ${ }^{13}$ book on strategic planning and my book with Campbell on strategic planning in the U.S. Air Force. ${ }^{14}$ But the pattern is broadly evident. The reasons lie in path-dependencies in the management field and in the complex relation between management and social science, reasons that are not "lost to history." ${ }^{15}$ In any case, I seek to position this book by claiming that it engages equally with purposive theorizing of public organizations and with processual sociology, unlike a very large fraction of literature on management or public management.

In dealing with the general issue of this book's novelty and positioning, the idea of design science requires some depth of discussion, as Herbert Simon's 
Sciences of the Artificial has served as both a precedent and a contrast, and as some academics along the years have proposed that public management be cast as a design science. Some context needs to be provided in advance of this discussion, as suggested in Chapter 2, in particular.

As a matter of historical fact, Simon didn't say that management should be cast as a design science; he listed management - almost in passing - as a science of the artificial, alongside the exemplary cases of engineering and architecture. As widely known, Simon did put forward the term "design science." However, he coined this term to refer to research work that ought to be done to generate fundamental knowledge about problem-solving, and specifically about the creation of artificial systems through designing and organizational decision-making. In calling for a science of design, Simon was trying to neutralize stiff opposition to teaching design in some engineering programs and to teaching problem-solving in some management programs (including those at his own university). The basis of opposition was attributed to the accepted doctrine that proper professional practice derives from a practitioner's skillful application of knowledge that derives ultimately from scientific investigation. ${ }^{16}$ Thus, a science of design was envisioned as a means to generate the fundamental knowledge on which teachers of engineering and management could draw, in both fashioning - and legitimating - courses on design in engineering schools and problem-solving in the modern management school.

Perhaps the most common meaning of a design science in management is that theory based on cumulative inquiry about human behavior in organizations should be applied directly by professional practitioners when they deliberate over choices between alternative mechanisms for coordinating and motivating human activity in organizations. ${ }^{17}$ However, this idea is far from Simon's idea of a design science; and it is not wholly in tune with his idea that problem-solving is the essence of the professional practice of management. For Simon, problemsolving wasn't about using theory for applied purposes, or about solving problems on the basis of theory - not that Simon would have scorned any of those ideas. Problem-solving was about participating in scenario-processes, whose initial conditions include individual insights, but collective ignorance, about an enterprise's problems and solutions. The scenario-process he had in mind was a design-project, constituted by the activities of designing and decision-making. Thus, disambiguation is needed when the term design science is invoked in the field of management.

Let me say how I position this book relative to Simon's ideas as put forward in Sciences of the Artificial. I'll start with two points of agreement. First, management ought to be a professional discipline that teaches designing enterprises, and problem-solving more generally, to professional practitioners. More stridently, the professional discipline of management should be engaged with preparing professional practitioners for problem-solving for enterprises, not just with decision-making for one or another functional domain, like finance, marketing, or production. Second, it should develop professional practitioners' competences for problem-solving, as well as their professional knowledge about the enterprises that they will be involved in creating, through design-projects, or 
otherwise. These two points of agreement head toward an implication: academic institutions in the field of management should encourage faculty to develop a design-oriented professional discipline, concerned with creating professional knowledge about management, problem-solving, and the relation between the two, as well as with developing professional practitioners' competence in problem-solving for enterprises.

This implication is stretched here to apply to public management, as follows: academic institutions should encourage faculty to develop a design-oriented professional discipline, concerned with creating professional knowledge about management, problem-solving, and the relation between the two, as well as with developing professional practitioners' competence in problem-solving for public organizations within governmental and societal institutions. A similar statement can be made for government-based schools of public administration.

By way of positioning, I would now like to note some contrasts between this book's idea of a design-oriented professional discipline of public management and Simon's views about management as a professional discipline, as far as these views are evident. They are to do with purposive theorizing, learning from experience, and competences of professional practitioners. I'll take them up, in turn.

This book makes a big deal of purposive theorizing. However, there's no mention of this term in Sciences of the Artificial, and there's no other term in that volume that has the same significance. I believe that purposive theorizing is important to the professional practice of management, and to the professional discipline of public management. In public management, purposive theorizing concerns the purposeful phenomena of public organizations, design-projects, and professional activities - taken individually and together. For professional practice, such purposive theorizing has specific practical implications for professional activities. For example, purposive theories of public organizations have practical implications for what observations and assessments to make as a professional practitioner engages in sense-making. For example, the idea that a public organization depends on support from its authorizing environment implies that sense-making should eventuate in observations about the interests and power of a public organization's multitude of stakeholders. Similarly, the idea that a public organization's functions include program delivery and management implies that sense-making should eventuate in observations about its value-chain configuration. Similar kinds of points can be made about the other professional activities: for example, designing should eventuate in an adequate value chain configuration - and its corresponding scenario- or conversion-processes - for whatever functions fall within the scope of the design-project at issue. As another example: dramatization should eventuate in a "routine" that projects ideas about design-oriented problem-solving, the mechanism of design-projects, and the professional activity of designing.

At the risk of digression, I don't see high-level statements about administrative philosophies ${ }^{18}$ like cameralism, progressive public administration, the post-bureaucratic paradigm, new public management, public value governance, network governance, and the like as particularly good examples of purposive theorizing about public organizations. But I do think that serious critical 
examinations of administrative philosophies, including these, using a range of standard principles and methods of analyzing practical argumentation, can eventuate in contributions to what I call purposive theorizing of public management: see, for example, my New Public Management, ${ }^{19}$ chapters 4 and 5, and, with caveats, my Breaking Through Bureaucracy, ${ }^{20}$ chapters 2,7 , and 8.

By comparison, Simon's stereotypical writings about management-related topics were downbeat on purposive theorizing. Take, for example, Simon's famous article, "The proverbs of administration," ${ }^{21}$ which took aim at classical administrative theorizing about organizational design. To say this critique of principles of administration was downbeat on purposive theorizing is nothing short of an understatement. Indeed, in that reputation-establishing piece, Simon didn't even bother to use standard principles of critical assessment of practical argumentation, such as being charitable toward an opponent's presentation of an argument, as you are interpreting and representing it, in order to avoid committing the strawman fallacy. When it came to setting out the idea of "administrative analysis," in the same piece, Simon didn't point out that he was using some established purposive theories, like aspects of scientific management, to warrant some of his own position. It shouldn't be overlooked that Simon wrote this article before the renaissance of philosophical work on practical argumentation, the beginning of which is often credited to Stephen Toulmin's Uses of Argument, ${ }^{22}$ which eventually made huge inroads into discussions of public policy analysis and public administration. And even Simon's own late-career work - Reason in Human Affairs ${ }^{23}$ - reflected the argumentative turn. Still, the stereotype of Simon, within public administration, is that of being scornful of purposive theorizing, at least when he wasn't discussing decision-making.

Simon's attitude toward purposive theorizing in Sciences of the Artificial isn't easy to discern. Consider his adopted idea that designing is constituted by analysis and synthesis -two interlocking scenario-processes with contrasting contextaction-outcome profiles, in the language of this book. Analysis was presented as being channeled by knowledge of some range of domains that came to be identified as relevant to the design-project at issue. The term "domain knowledge" later came into use as a handy reference to this idea. In the context of Sciences of the Artificial, which was heavily concerned with engineering design, domain knowledge connoted technical knowledge and expertise. From that volume, it's not really clear what Simon thought would be "domain knowledge" for management, apart from his own theorizing about organizational design and decision-making (which, in any event, he appeared to assign to the category of design knowledge). What is clear is the following: purposive theorizing of enterprises was not Simon's cup of tea, while Sciences of the Artificial was not centrally concerned with the professional discipline or practice of management.

Bottom line: When I say that purposive theorizing about enterprises, including public organizations, counts as professional (or domain) knowledge for management, or public management, I am presenting a view that diverges from stereotypes of Simon's idea of sciences of the artificial, that is, his term for design-oriented professional disciplines. It is also out-of-tune with respect to the tenor of much of his writing about management. However, I don't think there 
is a fundamental clash - or incompatibility - in perspective. My view is there is much to be gained from energetically updating Simon's theorizing about professional disciplines, including management, so that it makes sense, and can thrive, after the argumentative turn in social science, philosophy, and beyond.

Learning from experience is a second point of dissonance or departure. This point was discussed at some length in Chapter 6. Suffice it to say here that Simon's theorization of designing as a professional activity, and of the analysis aspect of design-projects, was essentially silent on this topic. In this respect, his theorization of designing was thin, to put the point gingerly. There are reasons of intellectual history that explain this deficit; some of which have to do with the setting within which Simon did his earlier work and some have to do with his focus on decision-making as a theoretical frame about management. Be that as it may, the position taken in this book is that design-precedents count as professional (or domain) knowledge, as does purposive theorizing. That position points toward a wide-open challenge of studying past manifestations of purposeful phenomena, within a professional discipline, with a view to creating design-precedents.

I don't see any clash between this position and Simon's, even though the creation and use of design-precedents isn't stereotypical of the ideas in Sciences of the Artificial. (I'm ignoring here a few salient passages in the first chapter, which suggest that the study of artificial phenomena should include methods for analyzing past artifacts, so that, as the saying goes, humankind is not damned to reinventing the wheel, repeatedly.) That said, it seems to me that what's truly missing from Simon's account of design-oriented professional disciplines is how to investigate past manifestations of purposeful phenomena, so that the material I call a design-precedent is meaningful, in the course of design-projects, when it is being used in combination with purposive theories.

Bottom line: in my view, the understandable silence on purposive theorizing, combined with strange silence on design-precedents, makes Simon's Sciences of the Artificial, altogether, a weak precedent for a design-oriented professional discipline of management or public management. We need such a discipline: Simon, however, doesn't provide the blueprint, after all. If it's going to happen, we need to develop it ourselves. That's a big ask: about which, more later.

A third contrast with Simon concerns professional competences. The contrast is not altogether stark - certainly less so than the contrast between Sciences of the Artificial and this book's position on purposive theorizing and design-precedents. Here's the common ground. First, Simon theorized professional competences by putting the emphasis on how thinking and communicating played roles in the emergent processes (to effectuate problem-solving) that eventuate in scenario outcomes; in this respect, his general approach to theorizing professional competences was quite in line with processual sociology - unsurprisingly, as they stemmed from a common source, not least the philosophical pragmatism of John Dewey. (The commonplace idea that competences consist in knowledge, skills, and attitudes is cut from different philosophical cloth.) Second, Simon put great store in designing as being a professional competence. Its attributes include the ability to make good choices about how to "search" for knowledge 
and information, as well as to judge its relevance and implications for problemsolving, during further stages of a design-project. Third, Simon considered creativity to be a kind of professional competence, though one that is a bit hard to teach. Fourth, Simon saw being able to participate in design-projects within organizations as a competence: hence, he emphasized that engineers had to learn about how decision-making in organizations works. Finally, Simon implicitly put a high value on the competence of framing, formulating, and expressing a practical argument; though he didn't use the words, it's clear that his purposive theory of decision-making in organizations was in line with this view.

This book's purposive theorizing about public management takes all of this on board. The resulting form was evident in Chapter 4 - specifically, the audio guide presentation of the mezzanine and lower floors of the Public Management Gallery. The gallery layout made a distinction between design-projects (presented on the mezzanine floor) and professional activities (presented on the lower floor). In this theorization, designing is a professional activity, while a design-project is its context. Put the other way around, designing as a professional activity is a constitutive mechanism of a design-project. Both designprojects and designing have their complementary roles in this line of purposive theorizing about public management.

Disentangling design-projects from designing allows us to see that Simon's theorization of professional-competences-for-problem-solving was too narrow. The natural remedy is to expand the theoretical scheme, with the result being a construct consisting in the professional activities of sense-making, designing, argumentation, and dramatization. As mentioned, this idea was introduced toward the end of Chapter 4; it is developed slightly further and presented in tabular form, in Table 8.1.

The contrast between this table and Simon's idea of the competences of a professional practitioner are muted, insofar as one's attention is limited to sensemaking, designing, and argumentation. However, the contrast becomes striking as soon as one gazes at the column titled "dramatization." The view taken here is that problem-solving isn't effectuated by (a) creating representations of objectdesigns, plus (b) formulating practical arguments, unless (c) the participating professional practitioners dramatize agendas, context, actors, action, conceptual and embodiment designs, choice alternatives, authoritative actions, and more. That's a quite conventional view, with plenty of theoretical and empirical precedents in processual sociology (where one might pigeonhole Goffman), and elsewhere. But it's not stereotypical of Simon's idea of design-oriented professional practice; because his processualism was more philosophical (along the lines of Dewey) than sociological (along the lines of the Chicago School of Sociology), as much lamented by his 1950 s collaborator, James G. March. With a nod in the latter direction, there's no reason to be constrained by such path-dependencies in the field of management. Hence, this book's idea of professional practice includes the professional activity of dramatization, seen in mechanism-intent terms, as a constitutive mechanism of design-projects and, more inclusively, of public organizations.

Bottom-line: Simon's Sciences of the Artificial is a huge precedent for this book; 
Table 8.1 Mechanism-intent analysis of professional activities in public management

\begin{tabular}{|c|c|c|c|c|}
\hline $\begin{array}{l}\text { Professional } \\
\text { activity }\end{array}$ & Sense-making & Designing & Argumentation & Dramatization \\
\hline $\begin{array}{l}\text { What's it } \\
\text { for? }\end{array}$ & $\begin{array}{l}\text { Effectuating } \\
\text { design-projects; } \\
\text { Problem-solving; } \\
\text { Performing } \\
\text { functions; } \\
\text { Creating public } \\
\text { value }\end{array}$ & $\begin{array}{l}\text { Effectuating design- } \\
\text { projects; Problem- } \\
\text { solving; Performing } \\
\text { functions; Creating } \\
\text { public value }\end{array}$ & $\begin{array}{l}\text { Effectuating } \\
\text { design-projects; } \\
\text { Problem-solving; } \\
\text { Performing } \\
\text { functions; } \\
\text { Creating public } \\
\text { value }\end{array}$ & $\begin{array}{l}\text { Effectuating design- } \\
\text { projects; Problem- } \\
\text { solving; Performing } \\
\text { functions; Creating } \\
\text { public value }\end{array}$ \\
\hline $\begin{array}{l}\text { What's the } \\
\text { outcome? }\end{array}$ & $\begin{array}{l}\text { Observations } \\
\text { about a public } \\
\text { organization; } \\
\text { Ideas for } \\
\text { problem-solving; }\end{array}$ & $\begin{array}{l}\text { Coherent conceptual } \\
\text { and embodiment } \\
\text { designs for a public } \\
\text { organization; } \\
\text { Alternatives for } \\
\text { decision-making }\end{array}$ & $\begin{array}{l}\text { Arguments } \\
\text { about problems, } \\
\text { solutions, } \\
\text { and decisions } \\
\text { concerning } \\
\text { a public } \\
\text { organization }\end{array}$ & $\begin{array}{l}\text { Collective } \\
\text { representations of } \\
\text { agendas, context, } \\
\text { actors, action, } \\
\text { conceptual and } \\
\text { embodiment } \\
\text { designs, choice } \\
\text { alternatives, and } \\
\text { authoritative actions }\end{array}$ \\
\hline $\begin{array}{l}\text { What } \\
\text { conditions } \\
\text { channel it? }\end{array}$ & $\begin{array}{l}\text { Events leading } \\
\text { to the present; } \\
\text { Professional } \\
\text { knowledge }\end{array}$ & $\begin{array}{l}\text { Outcomes of sense- } \\
\text { making; Professional } \\
\text { knowledge } \\
\text { (including design } \\
\text { precedents); Initiated } \\
\text { design-projects }\end{array}$ & $\begin{array}{l}\text { Outcomes of } \\
\text { sense-making } \\
\text { and designing; } \\
\text { Professional } \\
\text { knowledge }\end{array}$ & $\begin{array}{l}\text { Outcomes of sense- } \\
\text { making, designing, } \\
\text { and argumentation; } \\
\text { events leading to } \\
\text { the present }\end{array}$ \\
\hline
\end{tabular}

but it is an insufficient - and in some ways, weak - basis for theorizing public management as a design-oriented professional discipline. Apart from the fact that figuring this out took me a decade of my professional life, that's fine. That's no burden for you. You now have something better to work with than I had when I started down this path.

The final step in positioning this book has to do with the idea that public management is a professional discipline. To be clear, I am not presenting public management as a profession, with manifest jurisdictional claims over membership, knowledge, and practice. Indeed, I haven't even discussed the relationship between public management, public administration, public policy, and management. I am hoping to draw people to the idea, irrespective of whether they happen to be placed institutionally within public administration, management, or public policy - or for that matter, outside academia. That raises a question about how to position this book's argumentation, in relation to the idea of a professional discipline.

As you can tell by now, the main precedent I have in mind is Simon's idea of a science of the artificial, which is a very high-level idea about a professional discipline. Not only is it high-level, Simon's idea is essentially presented in 
mechanism-intent terms, rather than in institutional ones. That is equally true of the way I presented public management as a professional discipline in this book, all the way back to Chapter 1 . There, I presented it, first, in terms of a program results chain, and then as two mutually enabling "enterprises," one for discipline-development and the other for teaching and learning. This abstract representation should be meaningful to anyone who aligns with the idea of public management being a design-oriented professional discipline.

You would rightly ask whether anyone has previously called for public management to be a design-oriented professional discipline, in as many words. To my knowledge, the answer is no. You can confirm this with a Google search, with the search-string of "public management design oriented professional discipline."

There was once a call for public administration to be a design science, in a piece by Shangraw, Crow, and Overman, in Public Administration Review. ${ }^{24}$ They stated:

As a design science, public administration can be separated from the behavioral sciences such as political science, psychology, or economics. In those fields of inquiry, the goal is to understand and predict particular types of human behavior in individual and social settings. ... Public administration, alternatively, draws knowledge from these fields and others, for the purpose of designing, constructing, and evaluating institutions and mechanisms for the public good. ... Defining public administration as a design science means that the role of the field is to design and evaluate institutions, mechanisms, and processes that convert collective will and public resources into social profit. (p. 156)

To me, the authors here are using the term "design science" merely to establish similarity between public administration and Simon's idea of a professional discipline concerned with purposeful phenomena. They display some mechanismintent theorizing of public administration. Public administration is for creating "social profit." Public administration consists in institutions and mechanisms, as well as their design and evaluation. However, there's little more to the similarity with Simon's idea of a science of the artificial than that. In fact, there's a bit less: the way they write about "the field" undercuts the distinction between a professional discipline - involving research and education - and actual practice. Indeed, the implication seems to be that the practice of public administration is a design-science, which has nothing to do with Simon's idea of a science of the artificial: as noted above, a design science is not a property of problem-solving; it's a basis for formulating and legitimating a course that teaches designing in engineering and problem-solving in management. All in all, the historical piece by Shangraw, Crow, and Overman is a negative precedent as far as this book is concerned. (Beware of "design science" as a label for public management as a professional discipline.)

While no one has previously called for public management to be a designoriented professional discipline, there are precedents for (a) the idea that designing is a distinctive professional activity within the professional practice of public 
management, and for (b) the idea that public management is a professional discipline. I consider these works as design-precedents for this book - and to this extent, they are relevant for positioning.

To my mind, the precedent for the idea that designing is a distinctive professional activity within the professional practice of public management is a pair of writings by Eugene Bardach, now professor emeritus of public policy at University of California, Berkeley. The writings are Getting Agencies to Work Together: The Practice and Theory of Managerial Craftsmanship, ${ }^{25}$ and "Presidential Address: The extrapolation problem - how can we learn from the experience of others?"26 As suggested by its title, the book presents the idea of designing as a professional activity using the terminology of managerial craftsmanship. The presidential address, discussed at some length in Chapter 6, illustrates the idea of mechanism-intent thinking when the purposeful phenomena are programs and when the mechanisms for performing a program's functions are analyzed as scenario-processes, with context-activity-outcome dynamics. The argument is that professional practitioners should engage in such thinking when they practice public management - specifically, when they (a) observe, analyze, and assess a program's source site, (b) extrapolate the results of this learning scenario to the challenge and situation in a program's target site, and (c) when they actually engage in specifying a program design there. Bardach's presidential address was also a precedent for my earlier article on case study research, ${ }^{27}$ which developed into the idea of design-focused case studies and design-precedents in this book, as presented in Chapter 6.

The precedent for the idea that public management is a professional discipline is Lawrence Lynn's Public Management as Art, Science, and Profession. ${ }^{28}$ Indeed, Lynn's book is a precedent in two senses. First, it was a book about a discipline that he calls public management: he argues that it is profession-like, however much of the research supporting it is scientific. Second, Lynn's book took a clear line about the doing of public management: namely that it's a professional practice, however much it might be instructive to probe an analogy between practicing public management and practicing an art. These similarities between Lynn's book and the present one are huge. I don't know of any other work that argues these two positions together, though there are some older works in public administration - not too well known - that can be cited as strong precedents. ${ }^{29}$

While Lynn's book was an abiding precedent for this one, it's really different in substance. First, its scope of discussion is vastly wider, as evident from how Lynn defined public management, that is, as performing the executive function in government. The phrasing as well as Lynn's commentary on the definition made clear that his book was concerned broadly with public administration. To that extent, Lynn was using the label "public management" to refer to what a decade or two earlier would have been labeled as "public administration." That's not to say that Lynn's book didn't deal with matters that figure centrally in public management: indeed, it includes a chapter that beautifully illustrates mechanism-intent thinking about change in a public organization - and that could be seen as an essay on the difference between drawing lessons from a case and formulating a design-precedent. However, when Lynn presented his broad 
pronouncements about public management being a professional discipline, these features of the book's discussion were essentially invisible. Bottom-line: the present book is exclusively about public management, while Lynn's was about public administration and public management, in varying proportions.

Second, Lynn's idea of a professional discipline was cut from different cloth than the idea that is presented here, under the label of a design-oriented professional discipline - particularly as he presented his thinking in the final, most programmatic chapter. Among the lines he took is that professional education in public management should consist in learning about a range of theories within a variety of disciplines, as well as in educational activities whose function is to make a practitioner more skillful at public management. To illustrate, some of the theories would be from institutional and organizational economics, while some others would be from political and legal theory. Skills would be built up from application exercises. So, you might ask: from what cloth was Lynn's position cut?

A step in answering this question is to be clear what fabric Lynn steered away from. The first is obvious: along the course of the book, Lynn made his disdain for Harvard case- and problem-based teaching painfully clear. There's also no evidence that Lynn had any interest in the intellectual tradition that formed the precedents for the content of such teaching, including the sort of mechanismintent thinking that was ushered into the field of administration by Henri Fayol. The second is less obvious: Herbert Simon's idea of sciences of the artificial, as it applies to management. Simon's idea of management as a professional discipline included teaching problem-solving. That's just not there.

Lynn's idea of a professional discipline seems to have come from elsewhere: a different sort of step is required to pinpoint it. That step is to look at the history of management in business schools in the U.S. - and specifically the immensely revealing volume by Mie Augier and James G. March. ${ }^{30}$

Augier and March lay out the rivalry between the "modern management school," embodied during the 1950s in the Graduate School of Industrial Administration at Carnegie Institute of Technology, and Harvard Business School's longer-standing approach. They also point out that the modern management school included a dominant and a heterodox position. The dominant position was modeled on the modern medical school, focused on developing a range of functional disciplines of management (e.g., finance and marketing) through theory development and empirical research aligned closely with economics and/or psychology. The heterodox position was that of Herbert Simon and his close collaborators (like March), focused as it was on problem-solving about enterprises - and within organizations. The line taken by "the modern medical school" wing was that becoming a professional practitioner requires the study of relevant scientific disciplines, followed by applications to gain skill in applying that knowledge in the making of business decisions.

The inference I draw is that Lynn's idea of public management as a professional discipline was cut from the cloth of the modern medical school. By contrast, the present book's idea of a design-oriented professional discipline was cut from the two rival traditions of the modern medical school, as it took form in the field 
of management: namely, the Harvard and Simon ones. Thus, Lynn's book is a precedent for the present book by virtue of its form (i.e., a full-length discussion of public management as a professional discipline), but not in its content.

I haven't sought to position this book in relation to recent publications in the business management field. One of the reasons is that I don't know of any book that actually works out a coherent position on business management as a design-oriented professional discipline. There are widely recognized works on design thinking, as an approach to product and service design: that relates to the professional activity of designing and, to a limited extent, to design-projects. But that's all. The volume that has the most topical similarity to the present book is an edited book by Richard Boland and Fred Collopy, ${ }^{31}$ entitled Managing as Designing. This book claims to develop the idea of bringing a design attitude to management, one that contrasts with "the more traditionally accepted and practiced decision attitude." It's clear that this book builds on Simon's idea of a design-project, which trades on the design/decision distinction. It's also majestic in style. But I wouldn't say that it works out the idea of a design-oriented professional discipline of business management in the way that the present volume does for public management. I've spotted some other successor works, but my assessment is similar.

The bottom line is that, while you could have surmised from this book's title what it is for, you couldn't have guessed what it consists in. The underlying reasons are, as follows. First, you can't find a precedent in the public management literature that is a full-dress discussion of public management as a design-oriented professional discipline. Second, this book's approach to public management is not closely aligned with any stereotypical reference point - not in business management, not with evidence-based policy or management, not with New Public Management, not with traditional public administration, and not even entirely with Sciences of the Artificial.

The point lingering in the shadows is this: public management should not be seen as a discipline whose future has been foretold by the other disciplines with which it is institutionally and historically aligned. Public management need not be a follower of developments in other fields: as a discipline, we can lead the way to learning how to embody the idea of a design-oriented professional discipline, involving management and public administration, in universities and government-based schools of public administration.

This book has extensive implications for the discipline-development and teaching-and-learning enterprises of the design-oriented professional discipline of public management. Indeed, I've "laid it out there" throughout this book, especially in the dialogues centered around Marshall, the barely fictionalized professor of public management, who you first met in Chapter 1. As you can tell by those dialogues, as well as every chapter of this book, I'm asking a lot of many hundreds of real-world Marshalls, Noras, Oliviers, and Petras. My hope is that what today looks like a Big Ask will seem - in retrospect - a rather modest one. That's an appropriate test of progress for the design-oriented professional discipline of public management. 


\section{NOTES}

1 Craver and Darden (2013).

2 Moore (1995)

3 Schön (1983).

4 Simon (1996).

5 Lawson (2004).

6 Sarasvathy (2008).

7 Pawson and Tilley (1997).

8 Mintzberg (1983).

9 Porter (1985).

10 Abbott (2016).

11 Giddens (1984).

12 Latour (2005).

13 Bryson (2018).

14 Barzelay and Campbell (2003).

15 Augier and March (2011).

16 Simon (1996), Schön (1983).

17 Rousseau (2006).

18 Hood (1991), Hood and Jackson (1991).

19 Barzelay (2001).

20 Barzelay (1992).

21 Simon (1946).

22 Toulmin (1958).

23 Simon (1990).

24 Shangraw, Crow, and Overman (1989).

25 Bardach (1998).

26 Bardach (2004).

27 Barzelay (2007).

28 Lynn (1996).

29 Jun (2006).

30 Augier and March (2011).

31 Boland and Collopy (2004). 